\title{
IMPLEMENTASI KEBIJAKAN PEMBANGUNAN RUMAH LAYAK HUNI DENGAN PENDEKATAN HIBRIDA DI KABUPATEN SUPIORI PROVINSI PAPUA
}

\author{
Orthinus Ferdinando Samfar Kawer ${ }^{1}$ M. Baiquni ${ }^{2}$, Yeremias T. Keban ${ }^{3}$, dan Agustinus Subarsono ${ }^{3}$ \\ ${ }^{1}$ Program Studi S3 Studi Kebijakan Sekolah Pascasarjana Universitas Gadjah Mada \\ ${ }^{2}$ Fakultas Geografi Universitas Gadjah Mada \\ ${ }^{3}$ Fakultas Ilmu Sosial dan Politik Universitas Gadjah Mada \\ E-mail: orthinuskawer@gmail.com
}

\begin{abstract}
ABSTRAK, Kebijakan pembangunan perumahan menjadi instrumen pemerintah untuk melakukan intervensi pembangunan di daerah. Namun pembangunan rumah layak huni (RLH) dapat dijadikan sebagai sarana pemberdayaan masyarakat. Implementasi kebijakan pembangunan RLH perlu mempertimbangkan pendekatan kombinasi, yaitu pendekatan atas-bawah (top-down) dan pendekatan bawahatas (bottom-up), yang dikenal sebagai pendekatan hibrida. Paper ini bertujuan untuk menganalisis implementasi pembangunan RLH dengan pendekatan hibrida di Kabupaten Supiori dengan memperhatikan partisipasi masyarakat lokal dalam implementasi kebijakan tersebut. Penelitian ini menggunakan metode kualitatif deskriptif dengan pendekatan studi kasus. Data diperoleh melalui observasi partisipan, wawancara mendalam dengan pemerintah daerah, pemangku kepentingan maupun masyarakat penerima dana bantuan sosial RLH, dan dokumentasi. Hasil penelitian menunjukkan bahwa pembangunan RLH di Kabupaten Supiori telah dimulai sejak tahun 2012 dengan orientasi utama pemberdayaan masyarakat berpendapatan rendah. Pembangunan RLH ini dibiayai dengan dana bantuan sosial atau dikenal sebagai Bantuan Langsung Masyarakat (BLM) dari dana Otonomi Khusus. Perpaduan antara peran Pemerintah Kabupaten Supiori serta Kepala Distrik dan Kepala Kampung, dan peran masyarakat benar-benar sudah terlihat, yang merefleksikan pendekatan hibrida dalam implementasi pembangunan RLH. Masyarakat berpartisipasi aktif melalui tiga bentuk partisipasi, yaitu keterlibatan dalam sosialisasi dan musyawarah kampung, penyediaan material dan tenaga kerja lokal, serta manajemen konflik sosial akibat adanya kesan diskriminasi dalam penentuan prioritas penerima dana bantuan sosial pembangunan RLH. Dengan prosedur operasi standar yang dibuat, maka sulit bagi pemerintah daerah untuk berlaku dominan dalam intervensi masyarakat. Sebaliknya, prosedur operasi standar yang ada memungkinkan masyarakat berpartisipasi maupun mendampingi otoritas pemerintah daerah dalam melaksanakan kegiatan pembangunan RLH di masing-masing kampung prioritas.
\end{abstract}

Kata kunci: Implentasi Kebijakan Pembangunan; Rumah Layak Huni; Pendekatan Hibrida

\section{THE IMPLEMENTATION OF ADEQUATE HOUSING DEVELOPMENT POLICY USING HYBRID APPROACH IN SUPIORI REGENCY, PAPUA PROVINCE}

\begin{abstract}
Housing development policy is government's instrument to make intervention in local development. Adequate housing development can used to empower local community. It is necessary to consider a combined approach, i.e. top-down and bottom-up approaches, well-known as a hybrid approach. This paper aims at analyzing the implementation of adequate housing development with a hybrid approach in Supiori Regency by considering community participation. This study used a descriptive qualitative method with a case study approach. Data were collected through participant obvservation, in-depth interviews with local government authorities, stakeholders, and families receiving the social fund for adequate housing, and documentation. The results of the study show that the adequate housing development in Supiori Regency was started from 2012 and oriented to low-income community empowerment. The adequate housing development was funded using the Direct Fund for Community (Bantuan Langsung Masyarakat-BLM) from the Special Autonomy fund. The combined roles played by the Government of Supiori Regency, Heads of District and Village, and community were actually seen to reflect the hybrid approach in the adequate housing development. The community participated through three forms, i.e. involvement in socialization and consultation at village level, provision of materials and labors, and the management of social conflict due to discrimination in determining ones prioritized to gain the fund for adequate house development. With the prevailing procedures, it is difficult for government to intervent the local community development. Such procedures enabled community to participate and accompany the government in performing the adequate housing development activities in each priority village.
\end{abstract}

Key words: The Implementation of Development Policy; Adequate Housing; Hybrid Approach

\section{PENDAHULUAN}

Kebijakan perumahan (housing policy) masih sangat diperlukan, terutama di negara-negara berkembang. Di Indonesia, pergeseran kebijakan perumahan sejak akhir dekade 1990-an terjadi seiring dengan masuknya era reformasi sejak berakhirnya rezim otoriter Orde Baru tahun 1998. Menurut Monkkonen (2013), pembangunan perumahan di Indonesia didasari kondisi kekurangan perumahan akibat perubahan demografis, krisis ekonomi, dan tren formasi rumah tangga, terutama sejak akhir tahun 1990-an sampai tahun 2007. Kekurangan perumahan mendorong kebijakan peningkatan suplai perumahan melalui program intervensi pembangunan perumahan yang digagas oleh pemerintah dengan pendekatan atasbawah (top-down).

Kebijakan perumahan menjadi instrumen pemerintah yang sangat penting untuk melakukan intervensi pembangunan. Festus dan Amos (2015) menunjukkan bahwa kebijakan perumahan merupakan alat yang penting 
dalam upaya mendukung pembangunan nasional di Nigeria. Namun implementasi kebijakan pembangunan oleh pemerintah dengan pendekatan atas-bawah ternyata bermasalah, misalnya administrasi buruk, pendanaan tidak memadai, infrastruktur tidak mencukupi, dan pembiayaan perumahan kurang (Festus dan Amos, 2015). Masalah dalam implementasi kebijakan pembangunan atas-bawah ini umumnya juga ditemukan di negara berkembang seperti Indonesia, dalam kasus ini di Papua.

Dalam rangka mengatasi permasalahan pendekatan atas-bawah tersebut, perlu transformasi manajemen pemerintahan daerah, dari pendekatan atas-bawah menjadi responsif terhadap aspirasi bawah-atas. Transformasi manajemen pemerintahan daerah ini penting, terkhusus sejak diberlakukannya UU No. 22 Tahun 1999 tentang Pemerintahan Daerah (Redjo, 2009). Di Provinsi Papua, penerapan Otonomi Khusus melalui UU No. 21/2001 tentang Otonomi Khusus bagi Provinsi Papua memberikan kewenangan yang sangat besar bagi kepala daerah (bupati/ walikota) dalam melaksanakan kebijakan pembangunan berorientasi pemberdayaan masyarakat untuk mempercepat pengejaran ketertinggalan pembangunan, termasuk di bidang perumahan (Sumule, 2003). Pada era Otonomi Khusus, pembangunan perumahan bukan hanya merupakan instrumen kebijakan utama pemerintah, tetapi juga menjadi titik balik bagi partisipasi masyarakat dengan pendekatan bawah-atas dalam melaksanakan pembangunan perumahan di daerah, khususnya melalui pembangunan RLH. Hal ini karena untuk mencapai keberhasilan pembangunan masyarakat kampung, perencanaan, pelaksanaan, serta evaluasi pembangunan harus melibatkan masyarakat lokal, karena merekalah yang mengetahui permasalahan dan kebutuhan dalam rangka membangun wilayahnya dan merekalah nantinya yang akan memanfaatkan dan menilai berhasil atau tidaknya pembangunan di wilayah mereka (Daraba, 2017).

Salah satu kasus yang sangat menarik dikaji di Provinsi Papua adalah pembangunan RLH di Kabupaten Supiori. Daerah ini membutuhkan pembangunan fisik melalui penyediaan infrastruktur lewat pembangunan RLH dalam kerangka pengembangan wilayah. Banyak daerah masih tertinggal jauh dengan jarak berjauhan satu sama lain. Sarana dan prasarana perhubungan berupa jalan, transportasi dan komunikasi juga terbatas. Penduduk umumnya tinggal di daerah terisolir, di rumah yang tidak layak huni dan berjauhan satu sama lain, sehingga Pemerintah Kabupaten Supiori memainkan peran penting sebagai agen utama penyediaan RLH. Tujuan paper ini adalah menganalisis implementasi kebijakan pembangunan RLH dengan pendekatan hibrida di Kabupaten Supiori dengan memperhatikan partisipasi dari masyarakat lokal dalam implementasi kebijakan tersebut.

Dalam konteks pemerintahan daerah, pendekatan atas-bawah mengacu pada bagaimana suatu keputusan otoritatif dilaksanakan, baik di lokasi tertentu maupun banyak lokasi. Tokoh paling menonjol sebagai pendiri pendekatan atas-bawah generasi pertama adalah
Jeffrey Pressman dan Aaron Wildavsky (Parsons, 1995). Pendekatan ini memandang implementasi kebijakan yang ditulis dalam dokumen resmi yang diarahkan untuk mencapai tujuan yang ditetapkan dalam kebijakan. Menurut Matland (1995), pendekatan atasbawah menggeser fokus dari bagaimana naskah undangundang menjadi hukum dan hukum menjadi program.

Untuk mengevaluasi implementasi atas-bawah, beberapa pertanyaan dapat diajukan, yaitu: sejauh mana tindakan para pejabat pelaksana dan kelompok target telah sesuai dengan keputusan kebijakan, sejauh mana tujuan tersebut dicapai dari waktu ke waktu, apakah faktor utama yang mempengaruhi output serta dampak kebijakan baik yang relevan dengan kebijakan resmi maupun kebijakan lain yang penting secara politik dan bagaimana kebijakan direformulasi dari waktu ke waktu berdasarkan pengalaman (Sabatier, 1986: 22). Jadi, implementasi kebijakan publik dengan pendekatan atas-bawah memerlukan masukan atau umpan balik untuk perbaikan kebijakan bertahap dari waktu ke waktu.

Para teoretisi atas-bawah melihat para perancang kebijakan sebagai aktor sentral dan memusatkan perhatiannya pada faktor-faktor yang dapat dimanipulasi pada tingkat pusat. Di wilayah kebijakan, pembuat kebijakan atas-bawah biasanya memprioritaskan berbagai kebijakan yang jelas (Matland 1995). Pendekatan atasbawah memiliki kekuatan, salah satunya adalah berusaha mengembangkan nasihat kebijakan yang dapat digeneralisir dan mempunyai pola-pola konsisten yang dapat dikenali dalam perilaku di wilayah kebijakan berbeda (Matland 1995). Namun, pendekatan atas-bawah dikritik karena hanya mengambil bahasa undang-undang sebagai titik berangkat dan kurang mempertimbangkan pentingnya berbagai aksi sebelumnya. Pendekatan ini umumnya menganggap implementasi sebagai proses administratif dan mengabaikan atau menyingkirkan aspekaspek politik. Tekanan pada para pembuat undang-undang sebagai aktor kunci membuat pendekatan atas-bawah kurang memperhatikan para aktor dalam masyarakat di tingkat lokal.

Pendekatan bawah-atas berkembang sebagai respons terhadap kekurangan dari pendekatan atas-bawah. Pendekatan bawah-atas banyak berfokus pada variabel prediktor serupa seperti bentuk dan muatan kebijakan, organisasi dan sumberdaya, serta orang beserta bakat, motif, sikap dan hubungan antarpersonal termasuk pola komunikasi mereka. Tokoh pendekatan bawah-atas adalah Mazmanian dan Sabatier (1983), Ripley dan Franklin (1982), Ingram dan Mann (1980). Menurut Matland (1995), pendekatan bawah-atas mengakui implementasi kebijakan bervariasi dari waktu ke waktu di antara berbagai kebijakan dan dari satu daerah ke daerah lain.

Pendekatan bawah-atas mulai terjadi apabila otoritas publik menekankan pentingnya konsensus dan kepatuhan, dan mengakui pentingnya partisipasi dalam formasi kebijakan oleh 'bawahan'. Partisipasi bukan terjadi dalam implementasi kebijakan saja, melainkan sudah mulai 
pada tahap formasi kebijakan sebelumnya. Para teoretisi pendekatan bawah-atas menekankan kelompok-kelompok target dan pemberi pelayanan karena kebijakan itu dibuat pada tingkat lokal (Matland 1995). Pendekatan bawah-atas mengidentifikasi jejaring aktor yang terlibat dalam proses pemberian pelayanan di satu wilayah atau lebih dan bertanya pada mereka tentang tujuan, strategi, aktivitas, dan kontak mereka (Hanf et al., 1978). Pendekatan ini mengembangkan teknik jejaring untuk mengidentifikasi para aktor lokal, regional, dan nasional yang terlibat dalam perencanaan, pembiayaan, dan pelaksanaan program pemerintahan dan non-pemerintahan yang relevan. Jadi, terbentuk suatu mekanisme untuk bergerak dari aktor, pembuat keputusan lokal, dan masyarakat menuju pembuat kebijakan puncak di sektor publik (Sabatier 2005: 23).

Para aktor serta tujuan, strategi dan aktivitas mereka perlu dipahami untuk memahami implementasi. Pendekatan bawah-atas tidak memberi nasihat tentang kebijakan preskriptif, melainkan lebih mendeskripsikan apakah faktor-faktor yang menyebabkan kesulitan dalam mencapai tujuan (Matland 1995). Pendekatan ini penting dan strateginya fleksibel, sehingga dapat disesuaikan dengan kesulitan lokal dan faktor kontekstual. Akan tetapi, pendekatan ini mengalami kelemahan karena kontrol kebijakan seharusnya dilaksanakan aktor-aktor yang kekuasaannya menurun dari akuntabilitas mereka atas pemilih yang berdaulat melalui wakil-wakil terpilih mereka, tetapi otoritas para pemberi pelayanan pada tingkat lokal tidak mempunyai kekuasaan seperti itu. Pendekatan bawah-atas juga cenderung terlalu menekankan pada level otonomi lokal (Matland 1995).

Pendekatan hibrida merupakan pendekatan kombinasi (hybrid approach) dalam implementasi yang memadukan variabel utama dari pendekatan atas-bawah dan bawah-atas ke dalam kerangka tunggal. Pendekatan ini memadukan berbagai pendekatan, perbandingan lintas-kebijakan, tekanan pada peran dari negara sekaligus pengandalan pada analisis sistematis, khususnya untuk melihat variasi di berbagai latar, kebijakan, dan waktu dengan hasil yang diharapkan lebih komprehensif.

Helga Puzl dan Oliver Treib (dalam Fischer et al., 2007) mengemukakan bahwa teori-teori hibrida dalam implementasi kebijakan mendapat kontribusi dari beberapa pakar utama, antara lain Elmore (1978), Majone dan Wildavsky (1978), Scharpf (1978), Mayntz (1977), Windhoff-Heritier (1980), Ripley dan Franklin (1982), Sabatier (1986), Goggin et al. (1990), dan Winter (1990). Sebagai reaksi terhadap perdebatan antara pendekatan atas-bawah dan bawah-atas, para peneliti seperti Elmore (1978), Sabatier (1986), dan Goggin et al. (1990) berusaha untuk mensintesis kedua pendekatan tersebut, dengan memasukkan beberapa kelebihan masing-masing ke dalam model implementasi kebijakan mereka.

Implementasi kebijakan publik dengan pendekatan terpadu adalah sintesis di antara pendekatan-pendekatan alternatif, baik pendekatan atas-bawah maupun bawahatas, terutama untuk melihat ide-ide kunci dari masing- masing. Perspektif inovatif ini digagas oleh Richard Elmore (1978). Dalam perspektif ini, kebijakan dari atas dipertimbangkan, namun pilihan individu dan organisasi yang menjadi inti masalah kebijakan juga diperhatikan, demikian pula aturan, prosedur, dan struktur yang paling dekat dengan pilihan-pilihan tersebut, instrumen kebijakan yang ada untuk mempengaruhi berbagai hal tersebut serta kebijakan praktis yang layak untuk dapat mencapai tujuan kebijakan dari atas.

Selain mengakui pentingnya perencanaan dari atas, pendekatan hibrida juga berfokus pada tindakan individu sebagai titik berangkat yang memungkinkan mereka dilihat sebagai respons terhadap masalah atau isu dalam bentuk pilihan-pilihan di antara berbagai alternatif (Elmore, 1978). Dalam konteks ini aspek yang terpenting dalam implementasi kebijakan adalah tanggung jawab (responsibility) dan kepercayaan (trust). Hal ini karena tanggung jawab bicara tentang hubungan antara tujuan dan hasil, sedangkan kepercayaan bicara tentang proses penerapan kebijakan agar menimbulkan manfaat (Lane, 1987: 542). Lane berpendapat bahwa pendekatan atasbawah menekankan 'sisi tanggung jawab', sedangkan pendekatan bawah-atas menekankan 'sisi kepercayaan'. Intinya, implementasi kebijakan merupakan kombinasi antara tanggung jawab dan kepercayaan.

Dalam pendekatan hibrida, keberhasilan implementasi program tergantung pada pendekatan atas-bawah dan bawah-atas. Selain harus selalu mulai dengan pertimbangan mengenai instrumen kebijakan dan sumber daya yang tersedia bagi perubahan kebijakan, para pembuat kebijakan juga harus mengidentifikasi struktur insentif bagi para pelaksana dan kelompok-kelompok target kebijakan (Helga Puzl dan Oliver Treib (dalam Fischer et al., 2007:95). Bagi Sabatier (1986), pendekatan hibrida muncul dalam kerangka advokasi kebijakan yang sama dengan pendekatan bawah-atas ketika analisis dimulai dari masalah kebijakan dan berlanjut dengan rekonstruksi strategi dari aktor yang terkait dalam rangka memecahkan masalah. Dengan pergeseran pendekatan atas-bawah, Sabatier (1986) menekankan peran pembelajaran kebijakan dan pentingnya kondisi sosial-ekonomi eksternal yang bisa berdampak terhadap pembuatan kebijakan. Perpaduan arah dalam pembuatan kebijakan ini membawa implikasi terhadap pertimbangan atas-bawah dan bawah-atas dalam proses implementasi kebijakan.

Pemaduan antara pendekatan atas-bawah (variabel makro) dan bawah-atas (variabel mikro) dilakukan untuk mendapatkan kelebihan dari kedua pendekatan, mengurangi kelemahan kedua pendekatan dan memungkinkan levellevel berbeda bisa berinteraksi secara regular (Matland 1995). Goggin et al. (1990) menyatakan diri merupakan pendiri generasi ketiga dari model implementasi kebijakan, karena mereka berusaha menjembatani kesenjangan antara pendekatan atas-bawah dan bawah-atas. Mereka mengakui perspektif keputusan kebijakan yang didefinisikan secara terpusat untuk diimplementasikan oleh aktor-aktor di tingkat lebih rendah. Namun, mereka juga memahami 
bahwa pelaksana kebijakan juga merupakan aktor-aktor politik yang memiliki haknya sendiri dan hasil usahanya memerlukan proses negosiasi rumit antara pelaksana kebijakan dan otoritas-otoritas pemerintah pusat (Helga Puzl dan Oliver Treib, dalam Fischer et al., 2007: 96).

Menurut Helga Puzl dan Oliver Treib (dalam Fischer et al., 2007: 97), teori-teori yang mendasari pendekatan hibrida menimbulkan inovasi yang penting dalam teori-teori implementasi kebijakan. Teori-teori tersebut berusaha mengatasi kelemahan konseptual dari perdebatan yang terpolarisasi antara pendekatan atasbawah dan bawah-atas, dan memadukan pengarahan politik pemerintah pusat dan pentingnya otonomi daerah. Namun, implementasi kebijakan sering terjadi karena adanya banyak pemangku kepentingan yang berinteraksi diantara level-level yang berbeda sehingga para pembuat kebijakan pusat maupun aktor lokal penting bagi keberhasilan implementasi kebijakan.

\section{METODE}

Penelitian ini menggunakan metode kualitatif deskriptif dengan pendekatan studi kasus di Kabupaten Supiori. Penelitian ini berfokus pada implementasi pembangunan RLH di daerah yang sedang berkembang dengan pendekatan hibrida. Penelitian ini menggunakan data primer yang diperoleh langsung dari lapangan melalui observasi partisipan di lapangan dan wawancara mendalam serta data sekunder yang diperoleh dari berbagai dokumen yang berkaitan dengan topik penelitian. Pengumpulan data primer dibantu oleh informan informan kunci, yang ditemukan dengan teknik purposif atau sesuai tujuan penelitian, antara lain Kepala Badan Perencanaan Pembangunan Daerah (Bappeda), Kepala Dinas Sosial, Kepala Badan Pemberdayaan Masyarakat, petugas lapangan dalam pembangunan RLH, tokoh agama dan adat, otoritas distrik, kelurahan/kampung, tokoh pemuda dan perempuan, serta masyarakat yang menerima dana bantuan program pembangunan RLH di lokasi penelitian.

Peneliti turun lapangan secara langsung untuk melakukan observasi partisipan dan wawancara mendalam dengan informan kunci. Untuk mempermudah pelaksanaan penelitian, peneliti dibantu dengan beberapa alat wawancara seperti daftar pertanyaan semi-terstruktur sebagai panduan pengumpulan data yang relevan dengan indikator yang diteliti. Data yang dikumpulkan berhubungan dengan implementasi kebijakan pembangunan RLH, khususnya mengenai pelaksanaan kebijakan yang telah ditetapkan oleh Pemerintah Daerah Kabupaten Supiori untuk membangun RLH sebagai tempat tinggal dan sarana pembinaan keluarga dalam upaya meningkatkan kesejahteraan keluarga. Data yang terkumpul dianalisis dengan teknik analisis kualitatif. Mengacu pada pendapat Miles dan Huberman (2009), analisis kualitatif ini dilakukan melalui tiga alur kegiatan secara simultan: reduksi data, penyajian data, dan penarikan kesimpulan.

\section{HASIL DAN PEMBAHASAN}

Pembangunan RLH di Kabupaten Supiori pada dasarnya adalah stimulasi pemerintah daerah berupa dana yang diberikan kepada masyarakat yang berpenghasilan rendah untuk membantu pembangunan RLH. Rumah itu dibangun dengan prakarsa dan upaya dari masyarakat, baik secara sendiri atau berkelompok, meliputi perbaikan, pemugaran, perluasan atau pembangunan rumah baru serta lingkungannya. Pemerintah Kabupaten Supiori sadar mereka memiliki keterbatasan daya beli dan perlu diberi dukungan untuk memperoleh RLH. Kelompok sasaran penerima dana bantuan sosial pembangunan RLH adalah warga masyarakat kampung dengan mata pencarian tidak tetap dan tidak dapat memenuhi kebutuhan yang layak bagi kemanusiaan.

KondisirumahsebagianbesarmasyarakatKabupaten Supiori umumnya masih memprihatinkan, baik di daerah perdalaman, perdesaan maupun perairan dangkal pinggir laut. Di perdalaman, rumah penduduk biasanya dibangun berbentuk panggung untuk menghindari binatang liar dan dalam kurun waktu lama rumah panggung menjadi rumah tradisional daerah perdalaman Supiori. Di perdesaan, rumah dibangun langsung di atas pondasi tanpa panggung. Di perkampungan perairan dangkal pinggir laut, rumah dibangun di atas pancang kayu yang berjajar. Masyarakat belum memiliki rumah permanen dan sebagian besar berupa rumah tua yang sudah rusak. Kondisi rumah itu umumnya tidak layak huni dan masih banyak rumah induk ditinggali lebih dari satu kepala keluarga, terutama anak-anak yang sudah berkeluarga tetapi tetap tinggal di rumah orangtuanya karena mereka berpenghasilan rendah dan tidak mampu membangun rumah. Pada tahun 2012, banyak rumah di Kabupaten Supiori masih berbentuk sederhana dan tidak layak huni. Pemerintah daerah melihat rumah-rumah sederhana itu tidak layak huni dan perlu dibangun. Oleh karena itu, putra daerah, Fredrik Manufandu, sebagai Bupati terpilih periode 2011-2016 mempunyai prakarsa kebijakan membangun RLH bagi masyarakat kurang mampu. Program pembangunan RLH ini dilaksanakan sebagai wujud pemberdayaan potensi masyarakat dan pemerintah kampung dalam rangka mewujudkan kemandirian dan kesejahteraan masyarakat kampung.

\section{Pelaksanaan Pembangunan Rumah Layak Huni}

Pembangunan RLH dilaksanakan untuk masyarakat berpenghasilan rendah di 38 kampung se-Kabupaten Supiori sejak tahun 2012. Dana pembangunan itu berasal dari APBD Kabupaten Supiori Tahun Anggaran 20122015 sebesar Rp38.000.000.000 (Lampiran Tabel 1). Setiap kampung memperoleh dana bantuan sosial sebesar Rp1.000.000.000, yang dibagi menjadi 20 keluarga per kampung atau Rp50.000.000 per penerima. Jumlah dana bantuan sosial itu tidak dibedakan antara daerah-daerah yang berbeda, baik di perdalaman, perdesaan maupun perairan dangkal pinggir laut. Program ini dilaksanakan 
oleh Dinas PMPK Kabupaten Supiori sebagai bagian yang tak terpisahkan dari implementasi UU No. 21/2001 tentang Otonomi Khusus bagi Provinsi Papua sebagai amanat agar pemerintah dan masyarakat Kabupaten Supiori dapat berkreasi dan berinovasi dalam pembangunan daerah termasuk melalui pemberdayaan menuju kemandirian masyarakat kampung. Sejak dilaksanakan pada tahun 2012 hingga 2015, 3.000-an RLH berhasil dibangun oleh Pemerintah Kabupaten Supiori.
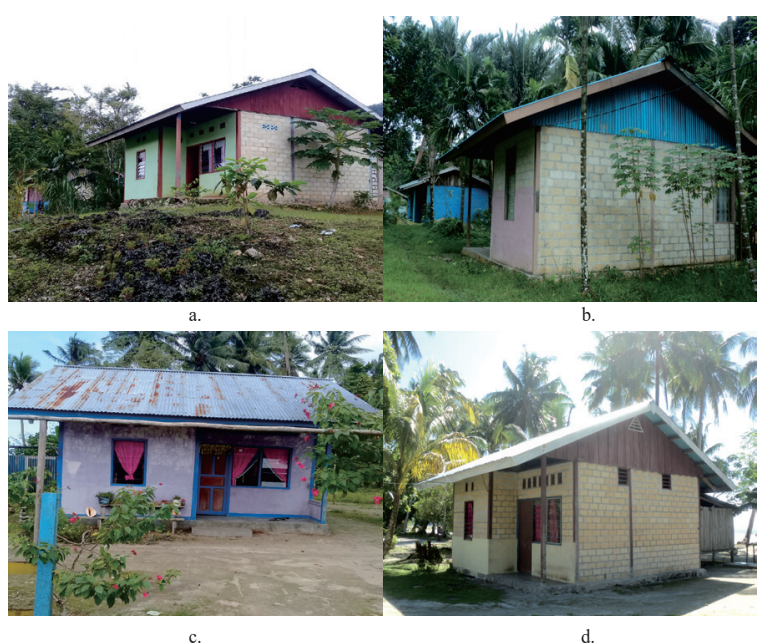

Gambar 1. RLH Terbangun Optimal di Kampung Waryesi, Distrik Supiori Timur (a); Kampung Warbefondi, Distrik Supiori Selatan (b); Kampung Amyas, Distrik Supiori Barat; dan (e) Kampung Fanjur, Distrik Supiori Utara

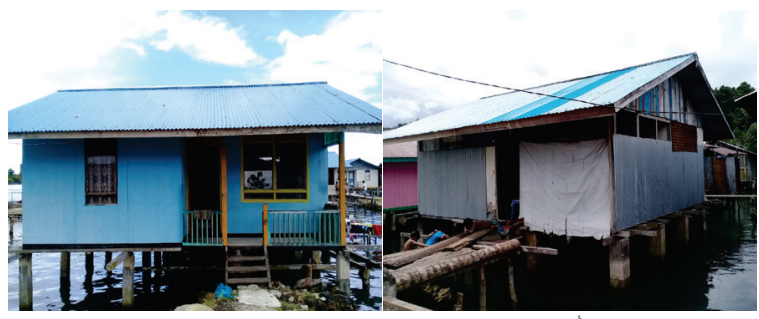

Gambar 2. RLH Terbangun Optimal (a) dan Kurang Terbangun Optimal (b) di Perairan Laut Dangkal Pinggir Pantai Kampung Rayori, Distrik Kepulauan Aruri

Pembangunan RLH di Kabupaten Supiori adalah wujud implementasi pembangunan yang berorientasi pada tata-kelola pemerintahan yang baik (good governance) dengan melibatkan peran aktif pemerintah daerah berdasar-kan prinsip transparansi dan akuntabilitas publik. Peran aktif ini ditunjukkan dengan adanya prakarsa pemerintah daerah (top-down) untuk meningkatkan keberdayaan potensi masyarakat dan pemerintah kampung melalui pembangunan RLH. Mengingat banyak masyarakat berpendapatan rendah dan selama ini belum mampu membangun tempat tinggalnya menjadi layak huni, maka Pemerintah Kabupaten Supiori berprakarsa aktif untuk memberikan dana bantuan sosial pembangunan RLH.

Di Kabupaten Supiori, otoritas pelaksanaan pembangunan RLH di setiap kampung didelegasikan khusus kepada Dinas PMPK. Sesuai dengan nama lembaga, PMPK mempunyai tugas utama melaksanakan program

Tabel 1. Pelaku dan Peran Pengelolaan Dana Bantuan Sosial Pembangunan RLH

\begin{tabular}{|c|c|c|}
\hline No & Pelaku & Peran Pengelola Pengguna Dana BLM \\
\hline \multirow[t]{6}{*}{1.} & Kabupaten & \\
\hline & a. Tim Koordinasi & Koordinasi sinkronisasi monitoring dan evaluasi \\
\hline & b. PMPK dan PKK & Penanggungjawab program pemberdayaan kampung \\
\hline & c. Dinas Keuangan & $\begin{array}{l}\text { - Memindah bukukan dana Bantuan Langsung Masyarakat (BLM) dari kas daerah ke rekening } \\
\text { dama block grant (BLM) } \\
\text { - Memindah bukukan dana dari rekening khusus ke rekening TPKK berdasarkan Surat Perintah } \\
\text { Membayar (SPM) dari PJOK Kabupaten (PMPK) }\end{array}$ \\
\hline & d. Satker (PJO Kabupaten) & Menerbitkan Surat Perintah Membayar (SPM) \\
\hline & $\begin{array}{l}\text { e. Kantor Cabang Kas Bank } \\
\text { Papua Kabupaten }\end{array}$ & $\begin{array}{l}\text { - Melakukan transaksi pencairan dana Bantuan Langsung Masyarakat (BLM) dari rekening khusus } \\
\text { ke rekening BLM di rekening kampung (nama kampung) } \\
\text { - Mengantar dana kesemua lokasi yang tercantum dalam surat keputusan ini } \\
\text { - Memberikan laporan bulanan realisasi penyaluran BLM kepada ketua tim koordinasi kabupaten } \\
\text { dan kepada Bank Papua }\end{array}$ \\
\hline 6. & $\begin{array}{l}\text { Distrik } \\
\text { a. Kepala distrik } \\
\text { (Penanggung jawab operasional } \\
\text { kegiatan distrik) }\end{array}$ & $\begin{array}{l}\text { - Melakukan verifikasi atas pengajuan rencana kerja dan penggunaan dana dari TPKK } \\
\text { - Menerbitkan surat persetujuan atas rencana kerja dan penggunaan dana oleh TPKK kepada } \\
\text { penanggung jawab program pemberdayaan kampung kabupaten (PMPK) } \\
\text { - Melakukan pengawan dan pembinaan terhadap proses perencanaan, pelaksanaan, dan } \\
\text { pertanggung jawaban keuangan kegiatan } \\
\text { - Menyampaikan laporan tertulis kepada Bupati tentang pelaksanaan program BLM secara berkala } \\
\text { (bulan, triwulan dan semester) }\end{array}$ \\
\hline 7. & $\begin{array}{l}\text { Kampung } \\
\text { a. Tim Pengelola Kegiatan } \\
\text { Kampung Kelurahan (TPKK) }\end{array}$ & $\begin{array}{l}\text { - Membuat Rencana Penggunaan Dana (RPD) dan Laporan Penggunaan Dana (LPD) } \\
\text { - Ketua TPKK menandatangani slip penarikan dari rekening kampung/ kelurahan } \\
\text { - mengelola dana BLM } \\
\text { - Menyampaikan slip penarikan dana pada saat musyarawah kampung kelurahan pertanggung } \\
\text { jawaban dana tahap I dan II }\end{array}$ \\
\hline 8. & $\begin{array}{l}\text { Wakil masyarakat yang dipilih } \\
\text { saat Muskam }\end{array}$ & Menandatangai slip penarikan dana dari Rekening Kampung/ Kelurahan (Rek, TPKK) \\
\hline 9. & Kepala Kampung/ Lurah & $\begin{array}{l}\text { - Menandatangani Surat Penetapan Kepala Kampung/ Kelurahan (SPKK) } \\
\text { - menandatangani slip penarikan dana dari Rekening Kampung/ Kelurahan (Rek, TPKK) yang } \\
\text { dikelola TPKK }\end{array}$ \\
\hline
\end{tabular}


pembangunan daerah yang berorientasi dasar pada pemberdayaan masyarakat dan pemerintahan kampung. Artinya, walaupun prakarsa awal program pembangunan yang dicanangkan berasal 'dari atas', baik Pemerintah Pusat maupun Pemerintah Daerah, orientasi utamanya tetap untuk meningkatkan keberdayaan masyarakat dan pemerintah kampung. Di tingkat kampung, Kepala Kampung adalah Panitia Program Pembangunan RLH untuk kampungnya. Kepala Kampung membuat rencana penggunaan dana dan membuat laporan penggunaan dana, membuat administrasi daftar tenaga kerja pembangunan RLH, mendokumentasikan nota-nota yang dibuat dalam penggunaan dana bantuan sosial selama proses pembangunan, dan mengambil foto dokumentasi pembangunan RLH. Dengan usulan pemerintah kampung melalui Badan Musyawarah Kampung, Pemerintah Daerah melalui PMPK menentukan lokasi dan alokasi ban-tuan sosial pembangunan RLH. Orientasi pemberdayaan masyarakat inilah yang menggeser pendekatan atas-bawah menjadi kombinasi dengan pendekatan bawah-atas atau sering disebut sebagai pendekatan hibrida.

Pengelolaan dana bantuan sosial pembangunan RLH di Kabupaten Supiori dilakukan dengan pedoman khusus yang dibuat untuk pembangunan kampung sebagai pegangan semua pelaku pengelola program, termasuk masyarakat, sehingga implementasinya bisa mencapai tujuan program dan menghindari agar tidak sampai terjadi kesalahan prosedur dan penyimpangan dana. Semua pelaku pembangunan RLH dan masyarakat harus mentaati petunjuk yang berlaku demi keberlanjutan pembangunan RLH di Kabupaten Supiori. Pengelolaan dana bantuan sosial pembangunan RLH itu dilaksanakan sebagai upaya Pemerintah Kabupaten Supiori dalam pengembangan kapasitas pengelolaan pembangunan RLH. Hal awal ini sangat penting dalam memberikan kewenangan lebih besar kepada masyarakat dan pemerintah kampung.

\section{Pendekatan Hibrida dalam Pembangunan RLH}

Pembangunan RLH di Kabupaten Supiori dilaksanakan dengan anggaran negara yang dibelanjakan untuk pembangunan perumahan masyarakat melalui dana Otonomi Khusus. Pembangunan RLH disertai penyediaan sarana dan prasarana umum yang mendukung. Di Kabupaten Supiori, peran pemerintah sebagai representasi dari negara sangat strategis dalam pelaksanaan pembangunan RLH karena masyarakatpenerima dana bantuan sosial berpenghasilan rendah dan tidak mampu membangun rumahnya sendiri. Pembangunan RLH menjadi tanggung jawab utama Dinas Pemberdayaan Masyarakat dan Pemerintah Kampung (PMPK). Dinas PMPK adalah unsur pelaksana yang menyelenggarakan urusan pemerintahan di bidang pemberdayaan masyarakat dan pemerintahan kampung yang menjadi kewenangan daerah.

DalampembangunanRLH,Dinas PMPKKabupaten Supiori memainkan peran yang strategis, khususnya dalam merumuskan sekaligus melaksanakan kebijakan teknis penyelenggaraan urusan pemerintahan di bidang pemberdayaan masyarakat daerah, pengelolaan keuangan dan aset kampung serta pemerintahan kampung. Dinas PMPK melaksanakan koordinasi, sinkronisasi, fasilitasi, dan kerjasama dalam mendukung pembangunan RLH. Di bawah Dinas PMPK, kebijakan pembangunan RLH dilaksanakan dalam rangka pemberdayaan masyarakat dan pemerintah kampung. Dengan pendekatan atas-bawah, pembangunan RLH sejak tahun 2012 dilaksanakan melalui beberapa tahap, antara lain: perencanaan, sosialisasi, pelaksanaan pekerjaan, revisi terhadap pelaksanaan pembangunan, dan penyelesaian kegiatan. Pembangunan RLH bertujuan memenuhi kebutuhan dasar masyarakat kampung, khususnya untuk memberikan pelayanan dasar perumahan dan permukiman sehat kepada masyarakat berpendapatan rendah atau kurang mampu.

Pada prinsipnya, pemerintah daerah melalui Dinas PMPK memainkan peran dominan dalam pelaksanaan pembangunan RLH. Namun, pemerintah daerah juga menyediakan ruang partisipasi masyarakat yang bertumpu pada prakarsa dan swadaya masyarakat untuk turut serta mengupayakan pengadaan dan pemeliharaan atas RLH yang dibangun sehingga dapat membangkitkan kepercayaan, kemampuan dan kekuatan sendiri, serta terciptanya kerjasama antara pemangku kepentingan dalam pembangunan RLH. Partisipasi masyarakat dalam pembangunan RLH diarahkan agar masyarakat semakin berdaya dalam pembangunan yang diadakan di daerah. Pemberdayaan ini dimulai dari proses pengajuan proposal dana bantuan sosial pembangunan RLH, pelaporan penggunaan dana, dan pembuatan dokumentasi proses dan hasil pembangunan. Dengan keterlibatan dalam proses dari awal hingga akhir tersebut, masyarakat menjadi lebih merasa memiliki program dan terlibat dalam pemeliharaan rumah yang terbangun. Selain itu, partisipasi masyarakat juga terlihat dari keterlibatan warga masyarakat dalam sosialisasi dan musyawarah kampung mengenai pembangunan RLH, dalam penyediaan material dan tenaga kerja lokal, serta dalam manajemen konflik sosial akibat diskriminasi saat penentuan penerima bantuan.

Di awal pencanangan pembangunan RLH di berbagai kampung Kabupaten Supiori, warga masyarakat kampung merasa senang terlibat atau ambil bagian dalam pelaksanaan program tersebut. Bagi masyarakat tidak mampu dan belum memiliki RLH, mereka mengharapkan prioritas mendapatkan dana bantuan sosial itu segera. Namun, mereka menyerahkan penentuan prioritas penerima dana bantuan sosial itu kepada tokoh masyarakat dalam acara sosialisasi dan musyawarah kampung pembangunan RLH. Penyerahan penentuan prioritas tersebut adalah salah satu indikasi keterlibatan warga masyarakat dalam mensukseskan pembangunan RLH. Inilah yang disebut partisipasi semi-aktif yaitu seolaholah tidak terlibat tetapi sebenarnya kepasrahan itu sangat mendukung keberhasilan pembangunan RLH. Logikanya, tidak dapat dibayangkan apa yang terjadi seandainya 


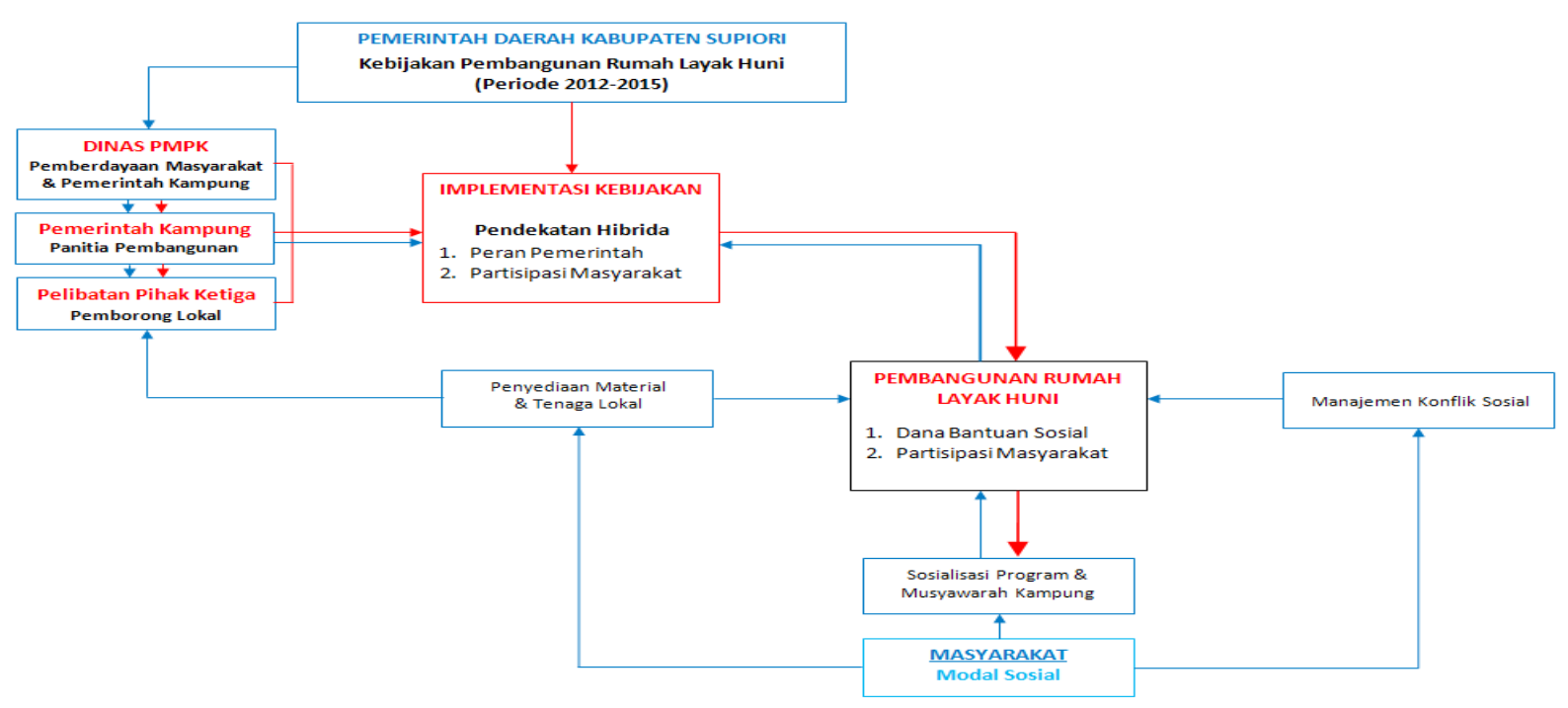

Gambar 3. Implementasi Pembangunan Rumah Layak Huni dan Bentuk-Bentuk Partisipasi Masyarakat Keterlibatan Masyarakat dalam Sosialisasi Program dan Musyawarah Kampung

warga sudah melakukan protes terhadap program pembangunan yang baru disosialisasikan. Jika banyak protes dalam tahap sosialisasi ini, pelaksanaan program akan menemui banyak kendala di lapangan. Penerimaan masyarakat atas siapa saja yang diberi dana bantuan sosial terlebih dulu oleh tokoh masyarakat menjadi kunci awal kesuksesan pembangunan RLH pada tahap selanjutnya. Jadi, warga menerima pembangunan RLH dan menerima prioritas penerima dana bantuan sosial tanpa protes. Sikap ini merefleksikan kepercayaan yang tinggi dari warga terhadap tokoh masyarakat, dalam hal ini kepala kampung dan sekretaris kampung, serta merefleksikan solidaritas tinggi terhadap warga masyarakat lain yang dipandang lebih berhak menerima dana bantuan sosial terlebih dahulu. Hal ini menjadi salah satu indikasi utama kuatnya modal sosial masyarakat kampung di Kabupaten Supiori.

Dalam pembangunan RLH di Kabupaten Supiori, musyawarah kampung memainkan peranan strategis dalam penentuan prioritas penerima dana bantuan sosial RLH. Dalam acara ini, partisipasi terjadi di sepanjang proses musyawarah, terutama dalam membahas perencanaan, pelaksanaan, dan evaluasi program. Partisipasi ini dilakukan, baik oleh aparat pemerintah maupun tokoh dan warga masyarakat kampung. Biasanya terdapat tiga pembahasan, yaitu penetapan 20 kepala keluarga penerima bantuan RLH; evaluasi dan pertimbangan kembali jumlah dana bantuan sosial sebesar Rp1.000.000.000 agar diusahakan ditambah sesuai dengan kondisi wilayah pembangunan yang berbedabeda; dan penetapan jadwal pelaksanaan pembangunan RLH. Jadi partisipasi bukan hanya melibatkan warga masyarakat, melainkan juga tokoh masyarakat seperti tokoh agama, tokoh pemuda, dan tokoh perempuan. Mereka menjadi bagian dari Tim Pengelola Keuangan dalam pembangunan RLH, khususnya terlibat dalam mengelola keuangan untuk memastikan dana bantuan sosial yang diberikan itu benar-benar dapat dialokasikan secara nyata untuk membangun RLH. Mereka bukan terlibat dalam perencanaan dan pelaksanaan pembangunan saja, melainkan juga dalam pengendalian, evaluasi, dan pelaporan pengelolaan urusan keuangan pembangunan RLH. Mereka bergerak bersama dalam Tim Pengelola Kegiatan Kampung (TPKK). Musyawarah kampung terbukti menjadi wadah partisipasi masyarakat yang efektif dalam pembangunan RLH di Kabupaten Supiori. Selain memberdayakan warga dan tokoh masyarakat dalam pengelolaan keuangan pembangunan RLH, musyawarah kampung menjadi wadah bagi aparat pemerintah kampung untuk melakukan sosialisasi agar warga masyarakat terlibat memutuskan siapa yang diberi prioritas menerima dana bantuan sosial tersebut terlebih dulu.

\section{Keterlibatan Masyarakat dalam Penyediaan Material dan Tenaga Kerja Lokal}

Di Kabupaten Supiori, ketersediaan material bangunan terbatas dan sulit diadakan dari luar, khususnya di daerah yang jauh dari ibukota kabupaten. Ini adalah salah satu kendala yang sulit diatasi dalam pelaksanaan pembangunan RLH, baik di daerah perdalaman maupun kepulauan. Selain karena sarana transportasinya sangat terbatas, biaya pengangkutan juga tinggi. Artinya, daerahdaerah yang berbeda dengan kondisi topografi yang berbeda mempunyai tingkat kemahalan berbeda pula, khususnya akibat masih terbatasnya bahan material untuk membangun RLH serta infrastruktur transportasi, baik lewat darat maupun laut. Dalam konteks ini, partisipasi masyarakat dalam penyediaan material dari sumber lokal terbukti sangat strategis dalam mendukung kelancaran pembangunan RLH, khususnya di perdalaman maupun kepulauan. Karena masyarakat merasa senang dengan dana bantuan sosial yang diberikan pemerintah, mereka dengan senang hati berusaha membantu pembangunan RLH yang dilaksanakan oleh pemerintah untuk mereka. Bantuan yang mereka berikan tentu saja sesuai dengan kemampuan yang dimiliki, yaitu bukan berupa uang karena mereka tidak memilikinya, melainkan penyediaan material bangunan, khususnya batu gunung untuk pondasi 
dan timbunan tanah untuk badan rumah, serta tenaga kerja. Selain menyediakan material bangunan berupa batu gunung atau batu karang untuk pondasi, timbunan tanah untuk badan rumah, serta balok-balok kayu untuk tiang, tidak sedikit warga masyarakat yang menerima bantuan sosial membantu menyediakan pasir untuk membangun rumahnya atau memotong kayu balok untuk keperluan pemasangan kap rumahnya. Mereka tidak menerima penggantian uang dari pemerintah dan tetap saja terlibat sebagai refleksi adanya partisipasi berbasis modal sosial karena mereka sudah merasa senang dibantu pemerintah dalam membangun rumah pribadi yang sebelumnya tidak layak huni. Fenomena ini unik dan cukup merata di berbagai kampung seluruh distrik di Kabupaten Supiori. Di satu sisi, pekerjaan penyediaan material terselesaikan warga masyarakat penerima dana bantuan sosial sendiri, sedangkan di sisi lain pemborong lokal sangat diuntungkan karena warga masyarakat penerima bantuan tidak mengharapkan penggantian biaya dalam pengadaan material tersebut. Mereka siap sedia untuk membantu pengadaan material bangunan yang dibutuhkan sesuai dengan kemampuan mereka.

Selain bantuan yang diberikan secara sukarela, ada juga partisipasi warga masyarakat yang berbayar, yaitu sebagai tenaga kerja lokal. Dalam pembangunan RLH di Kabupaten Supiori, salah satu wujud partisipasi masyarakat adalah keterlibatan tenaga kerja lokal dalam pembangunan RLH. Mereka terlibat sekaligus dibayar sesuai dengan kemampuan mereka serta sesuai dengan standar bayaran tenaga kerja lokal. Umumnya mereka terlibat membantu pengerjaan pondasi rumah, menyusun batako, pemasangan kap rumah, serta pintu dan paku seng. Bagi mereka, partisipasi masyarakat tidak lantas berupa keterlibatan tanpa bayaran, melainkan juga berupa keterlibatan dalam pembangunan dengan standar bayaran tenaga kerja lokal. Bayaran tenaga kerja lokal penting karena anggaran tenaga kerja memang sudah ada, jadi ada atau tidak ada tenaga kerja lokal, anggaran itu sudah seharusnya dikeluarkan. Tanpa ada partisipasi dalam penyediaan material bangunan dan tenaga kerja lokal, bisa dikatakan pembangunan RLH tidak terlaksana dengan baik dan optimal, terkhusus di daerah dengan topografi atau perairan yang sulit ditempuh. Di sini pentingnya tenaga kerja lokal sebagai wujud partisipasi masyarakat lokal dalam pelaksanaan pembangunan RLH.

\section{Keterlibatan Masyarakat dalam Manajemen Konflik Sosial}

Salah satu fenomena menarik yang ditemukan di lapangan adalah adanya kemampuan warga dan tokoh masyarakat di berbagai kampung seluruh distrik di Kabupaten Supiori untuk meredam potensi konflik akibat diskriminasi di dalam penentuan prioritas penerima dana bantuan sosial pembangunan RLH serta untuk mencari jalan keluar penyelesaian masalah di sepanjang pembangunan RLH. Warga masyarakat terlibat strategis sebagai objek sekaligus subjek pembangunan, yang sudah menerima atau belum menerima dana bantuan sosial tersebut. Warga masyarakat yang sudah menerima dana bantuan sosial itu tidak lantas terlalu senang secara berlebihan, melainkan tetap berendah hati dan menjaga perasaan warga masyarakat lain yang belum menerima dana bantuan sosial tersebut. Mereka selalu menghadiri acara yang berkaitan dengan pembangunan RLH walau mereka sudah menerima dana bantuan sosial tersebut. Mereka juga terbiasa mengikuti kegiatan gotong royong, seperti dalam penyediaan material bangunan untuk RLH yang dibangun belakangan pada tahun-tahun berikutnya. Sementara itu, warga masyarakat yang belum menerima dana bantuan sosial pembangunan RLH juga berendah hati untuk tidak dengan mudah tersulut kebencian dan permusuhan terhadap para penerima prioritas dana bantuan sosial tersebut. Mereka bersedia menerima sistem pergiliran dan mereka percaya nantinya mereka mendapatkan bagian serupa pada tahun berikutnya dengan semangat altruisme dan solidaritas, yaitu mengutamakan kepentingan dari warga masyarakat lain yang disepakati bersama lebih membutuhkan dibanding dirinya. Sikap rendah hati serta saling menjaga perasaan warga masyarakat lain ini menjadi refleksi terpenting dari kuatnya modal sosial yang dimiliki oleh warga masyarakat di berbagai kampung seluruh distrik Kabupaten Supiori.

Penerimaan warga masyarakat atas prioritas penerima dana bantuan sosial pembangunan RLHdapat ditemukan cukup merata di berbagai kampung seluruh distrik di Kabupaten Supiori. Kepercayaan masyarakat kepada Kepala Kampung dan Sekretaris Desa menjadi kunci utama kesuksesan pelaksanaan pembangunan RLH di berbagai kampung seluruh distrik Kabupaten Supiori. Adanya kepercayaan menjadi indikasi utama adanya unsur modal sosial yang kuat dalam diri sebagian besar warga masyarakat. Hal ini terbukti turut mendukung kesuksesan pembangunan RLH tanpa ada konflik dan keributan yang berarti akibat kesan diskriminasi, baik di antara warga yang sudah menerima dan belum menerima bantuan sosial maupun di antara warga masyarakat yang sudah dan belum menerima dana bantuan dengan Kepala Kampung dan Sekretaris Desa serta di antara mereka semua itu dengan kontraktor pelaksana pembangunan RLH. Fenomena masyarakat untuk menerima apa pun keputusan Kepala Kampung dan Sekretaris Desa menjadikan warga masyarakat tetap bersikap tenang dan saling menjaga solidaritas. Ini wujud paling penting dari partisipasi warga masyarakat dalam manajemen konflik sosial akibat munculnya diskriminasi saat penentuan prioritas penerima dana bantuan sosial pembangunan RLH.

Dalam mencegah munculnya kesan diskriminasi, Kepala Kampung biasanya menekankan pentingnya mendahulukan warga masyarakat yang mereka ketahui bersama benar-benar perlu diprioritaskan menerima dana bantuan sosial pembangunan RLH. Kebanyakan 
warga masyarakat percaya bahwa keputusan Kepala Kampung adalah keputusan terbaik dan dapat dipercaya karena semua warga yang pada dasarnya membutuhkan juga akan mendapatkan bagian pada tahun mendatang. Dalam meyakinkan warga, Kepala Kampung dibantu oleh Kepala Dusun, sehingga warga yang belum menerima dana bantuan sosial RLH menjadi lebih percaya mereka nantinya juga mendapatkan bagian. Jadi, peran Kepala Kampung terbukti strategis dalam menentukan prioritas penerima dana bantuan sosial RLH sampai tahapan pelaksanaan, pengawasan, evaluasi, atau bahkan pelaporan kegiatan pembangunan. Hal ini menjadi perhatian utama Kepala Kampung supaya konflik dan keributan tidak terjadi di tengah masyarakat akibat ada warga merasa bahwa dana bantuan sosial RLH dibagikan secara tidak adil.

Berdasarkan beberapa penjelasan tersebut di atas, dapat disimpulkan bahwa kebijakan pembangunan RLH di Kabupaten Supiori dilaksanakan dengan penerapan pendekatan bawah-atas dengan orientasi utama pada pemberdayaan masyarakat. Pemerintah Kabupaten Supiori berupaya meningkatkan peran masyarakat dengan mobilisasi sumber daya secara proporsional untuk mewujudkan RLH yang memadai. Salah satu indikasi utama pendekatan atas-bawah dalam pembangunan RLH adalah orientasi pada pembangunan RLH. Pemerintah daerah tidak otoriter dengan perencanaan murni dari atas, tetapi melakukan perencanaan dengan menyelami kebutuhan masyarakat. Karena masyarakat yang dibantu berpenghasilan rendah, rumah yang dibangun adalah rumah yang mampu memenuhi persyaratan keselamatan bangunan dan kecukupan minimum luas bangunan serta kesehatan penghuninya, yang dapat dijangkau oleh seluruh lapisan masyarakat. Penjelasan tersebut menunjukkan bahwa kebijakan pembangunan RLH di Kabupaten Supiori itu dibuat dan dilaksanakan dengan pendekatan kombinasi antara atas-bawah dan bawah-atas, atau dikenal sebagai pendekatan hibrida.

\section{SIMPULAN}

Pembangunan RLH di Kabupaten Supiori dilaksanakan sejak tahun 2012 dengan orientasi pemberdayaan masyarakat berpendapatan rendah. Pembangunan RLH ini dibiayai dengan dana bantuan sosial (BLM) dari dana Otonomi Khusus. Dana tersebut dikelola secara khusus dan ditransfer secara langsung ke rekening pemerintah kampung untuk menghindari kerumitan birokrasi. Dalam implementasinya, orientasi tata-kelola pemerintahan yang baik terlihat nyata. Perpaduan antara peran Pemerintah Kabupaten Supiori serta Kepala Distrik dan Kepala Kampung, dan peran masyarakat benar-benar sudah terlihat. Perpaduan ini merefleksikan kombinasi pendekatan hibrida dalam implementasi pembangunan RLH. Dalam kasus ini, masyarakat berpartisipasi aktif melalui tiga bentuk partisipasi, yaitu keterlibatan dalam sosialisasi maupun musyawarah kampung, penyediaan material dan tenaga kerja lokal, serta manajemen konflik sosial akibat kesan diskriminasi dalam penentuan prioritas penerima dana bantuan sosial pembangunan RLH. Dengan prosedur operasi standar yang dibuat, sulit bagi pemerintah daerah untuk berlaku dominan dan melakukan intervensi atas masyarakat. Sebaliknya, prosedur operasi standar yang ada memungkinkan masyarakat berpartisipasi untuk mendampingi pemerintah daerah dalam melaksanakan kegiatan pembangunan di masing-masing kampung prioritas.

\section{DAFTAR PUSTAKA}

Daraba, H.D. (2017). Pengaruh program dana desa terhadap tingkat partisipasi masyarakat di Kecamatan Galesong Utara Kabupaten Takalar, Sosiohumaniora, 19, (1), 52-58

Elmore, R.F. (1978). Organizational models of sosial program implementation, Public Policy, 26, (2), 185-228.

Festus, \& Amos, (2015). Housing Policy in Nigeria: An Overview, American International Journal of Contemporary Research, 5, (2).

Goggin, M.L., Bowman A.O., Lester J.P., \& O’Toole, L.J. (1990), Implementing Theory and Practice, England: Scott, Foresman and Company.

Lane, J.E. (1987). Implementation, accountability and trust, European Journal of Political Research, $15,(5), 527-46$.

Mazmanian, D.A. \& Sabatier, P.A. (1983) Implementation and Public Policy.Glenview, Ill.: Scott, Foresman.

Miles, B.M. \& Huberman, A.M. 2009. Analisis Data Kualitatif. Jakarta: UI-Press.

Monkkonen, P. (2013). Urban land-use regulations and housing markets in developing countries: Evidence from Indonesia on the importance of enforcement. Land Use Policy, 34, 255-264.

Parsons, W. (1995). Public Policy. Aldershot: Edward Elgar.

Redjo, S.I. (2009), Transformasi Manajemen Pemerintahan: Kasus Di Pemerintah Kota Bandung, Sosiohumaniora, 11, (3), 25-35.

Sabatier, P.A. (1986) Top-down and bottom-up approaches to implementation research: A critical analysis and suggested synthesis, Journal of Public Policy, 6, (1), 21-48.

Sumule, A. (2003). Mencari Jalan Tengah Otonomi Khusus Provinsi Papua. Jakarta: Penerbit PT. Gramedia Pustaka Utama. 